Article

\title{
Evaluation of the Antioxidant, Antidiabetic, and Antiplasmodial Activities of Xanthones Isolated from Garcinia forbesii and Their In Silico Studies
}

\author{
Johanis Wairata ${ }^{1,2} \mathbb{D}$, Edwin Risky Sukandar ${ }^{1} \mathbb{D}$, Arif Fadlan ${ }^{1}$, Adi Setyo Purnomo ${ }^{1}\left(\mathbb{D}\right.$, Muhammad Taher $^{3}(\mathbb{D}$ \\ and Taslim Ersam 1,*
}

Citation: Wairata, J.; Sukandar, E.R.; Fadlan, A.; Purnomo, A.S.; Taher, M.; Ersam, T. Evaluation of the Antioxidant, Antidiabetic, and Antiplasmodial Activities of Xanthones Isolated from Garcinia forbesii and Their In Silico Studies. Biomedicines 2021, 9, 1380. https://doi.org/10.3390/ biomedicines 9101380

Academic Editor: Maria Stefania Sinicropi

Received: 13 September 2021

Accepted: 1 October 2021

Published: 2 October 2021

Publisher's Note: MDPI stays neutral with regard to jurisdictional claims in published maps and institutional affiliations.

Copyright: (C) 2021 by the authors. Licensee MDPI, Basel, Switzerland This article is an open access article distributed under the terms and conditions of the Creative Commons Attribution (CC BY) license (https:// creativecommons.org/licenses/by/ $4.0 /)$
1 Department of Chemistry, Faculty of Science and Data Analytics, Institut Teknologi Sepuluh Nopember (ITS), Kampus ITS Sukolilo, Surabaya 60111, Indonesia; jhoeuniera@gmail.com (J.W.); edwin.risky.s@gmail.com (E.R.S.); afadlan@chem.its.ac.id (A.F.); adi.spurnomo@yahoo.com (A.S.P.)

2 Department of Agrotechnology, Faculty of Natural Science and Engineering Technology, University Halmahera, Jalan Wari-Ino, Tobelo, North Halmahera 97762, Indonesia

3 Department of Pharmaceutical Technology, Kulliyyah of Pharmacy, International Islamic University Malaysia, Bandar Indera Mahkota, Kuantan 25200, Malaysia; mtaher@iium.edu.my

* Correspondence: paktichem@gmail.com; Tel.: +62-813-3073-1952

\begin{abstract}
This study aimed to isolate xanthones from Garcinia forbesii and evaluated their activity in vitro and in silico. The isolated compounds were evaluated for their antioxidant activity by DPPH, ABTS and FRAP methods. The antidiabetic activity was performed against $\alpha$-glucosidase and $\alpha$-amylase enzymes. The antiplasmodial activity was evaluated using Plasmodium falciparum strain 3D7 sensitive to chloroquine. Molecular docking analysis on the human lysosomal acidalpha-glucosidase enzyme (5NN8) and P. falciparum lactate dehydrogenase enzyme (1CET) and prediction of ADMET for the active compound, were also studied. For the first time, lichexanthone (1), subelliptenone $\mathrm{H}$ (2), 12b-hydroxy-des-D-garcigerrin A (3), garciniaxanthone B (4) and garcigerin A (5) were isolated from the $\mathrm{CH}_{2} \mathrm{Cl}_{2}$ extract of the stem bark of $\mathrm{G}$. forbesii. Four xanthones (Compounds 2-5) showed strong antioxidant activity. In vitro $\alpha$-glucosidase test showed that Compounds 2 and 5 were more active than the others, while Compound 4 was the strongest against $\alpha$-amylase enzymes. In vitro antiplasmodial evaluation revealed that Compounds $\mathbf{2}$ and $\mathbf{3}$ showed inhibitory activity on $P$. falciparum. Molecular docking studies confirmed in vitro activity. ADMET predictions suggested that Compounds $\mathbf{1} \mathbf{- 5}$ were potential candidates for oral drugs. The isolated $\mathbf{2}-\mathbf{5}$ can be used as promising phytotherapy in antidiabetic and antiplasmodial treatment.
\end{abstract}

Keywords: Garcinia forbesii; xanthones; antioxidant; antidiabetic; antiplasmodial; molecular docking

\section{Introduction}

The genus Garcinia belongs to the family Clusiaceae of subfamily Clusioideae and tribe Garcinieae with more than 600 species are widely distributed in Africa, Asia, Australia, Polynesia, and Latin America [1]. Garcinia is mainly found in tropical rain forest of Southeast Asia and West Africa [2] and rich of secondary metabolites i.e., biflavonoids, xanthones, biphenyls, polyprenylated benzophenone, depsidones, and triterpenoids with various bioactivities. The aqueous extract of Garcinia combogia and ethyl acetate extract of Garcinia xanthochymus showed antioxidant activity [3,4]. Further, 6-O-methyl2-deprenylrheediaxanthone B, vieillardixanthone, forbexanthone, buchanaxanthone, isocudraniaxanthone A, and 5,7-dihydroxychromone have been isolated from the stem bark of Garcinia vieillardii and strongly active on DPPH assay [5]. Furthermore, polyisoprenylated xanthone guttiferone A from Garcinia aristata fruit displayed antiplasmodial activity against Plasmodium falciparum with $\mathrm{IC}_{50}$ values of $0.5 \mu \mathrm{M}$, comparable to chloroquine $\left(\mathrm{IC}_{50}\right.$ values of $0.3 \mu \mathrm{M}$ ) [6]. Mckeanianones A-E and new biflavone mckeaniabiflavone isolated from Garcinia mckeaniana had been reported active to P. falciparum strain TM4 and K1 [7]. 
Moreover, norcowanin isolated from the ethyl acetate extract of Garcinia oblongifolia twig actively inhibited $\alpha$-glucosidase enzyme with $\mathrm{IC}_{50}$ values of $1.7 \mu \mathrm{M}$ [8]. Fractination of ethyl acetate extract of Garcinia xanthochymus stem bark yielded xanthochymusxanthones $\mathrm{A}$ and $\mathrm{B}$ which showed significant activity toward $\alpha$-glucosidase [9].

Garcinia forbesii King is a member of Garcinia genus native to Sumatera and Borneo islands of Indonesia. This species is popular as forest red mangosteen in local community with sweet-sour taste of smaller size fruit than common mangosteen fruit (Garcinia mangostana L.). The peel of G. forbesii King fruit is commonly used as herbs and spices and provides sour taste in various types of dishes [10]. To the best of our knowledge, there is only one report on the phytochemicals of this species and there is no bioactivity evaluation of this plant so far. In 1993, Harrison [11] and co-workers reported the isolation of forbexanthone, piranojacareubin, and 1,3,7-trihydroxy-2-(3-methylbut-2-enyl)-xanthone from G. forbesii King. In this study, the extraction and isolation of active compounds from the stem bark of $G$. forbesii King were reported. The isolated compounds were then assayed for their antioxidant potential using 2,2-Diphenyl-2-picrylhydrazyl (DPPH), 2,2-azinobis3-ethylbenzothia-zoline-6-sulfonic acid (ABTS), and ferric reducing-antioxidant power (FRAP) methods along with in vitro antidiabetic assay ( $\alpha$-glucosidase and $\alpha$-amylase inhibitory activities) and in vitro antiplasmodial activity against $P$. falciparum strain 3D7 sensitive to chloroquine. The in silico studies were performed by molecular docking and absorption distribution metabolism excretion toxicity (ADMET) prediction to gain a deeper understanding of the correlation between the activities and oral drugs potency.

\section{Materials and Methods}

\subsection{General Experiment Procedures}

Vacuum liquid chromatography (VLC) and column chromatography (CC) (silica gel

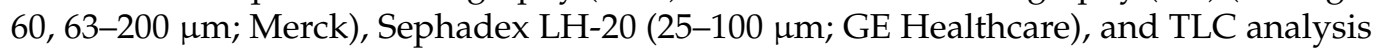
(silica gel 60 GF254, $0.25 \mathrm{~mm}$; Merck) were utilized for isolation of the compounds. Melting point was determined with Fischer-Johns melting point Apparatus (Philip Haris, Calgary, Canada). IR data were obtained using an FT-IR Spectrophotometer (Shimadzu 8400S, Kyoto, Japan). A UV-Vis Spectrophotometer (Genesys, Thermo Fisher Scientific, Madison, WI, USA) was used for UV-Vis spectra collection. The NMR spectra $\left({ }^{1} \mathrm{H} 400 \mathrm{MHz}\right.$ and ${ }^{13} \mathrm{C} 100 \mathrm{MHz}$ ) were recorded on NMR spectrometer (JEOL ECS, Tokyo, Japan) using the appropriate deuterated solvents. The HRESIMS spectra were collected by using a mass spectrometer (Water Xevo Q-tof MS, Milford, MA, USA). Docking study was performed with the Toshiba Portege Computer tool, Intel ${ }^{\circledR}$ Core TM i7-6600U CPU @ 2.60GHZ 2.80GHZ, 8.00 GB RAM, Intel HD Graphics 520. Molecular docking was studied by Molegro Virtual Docker 5.5. The structure of ligands was drawn by using ChemDraw 2018, minimized by Chem3D 2018, and saved as. mol2 format files.

\subsection{Plant Material}

The stem barks of G. forbesii King were collected from the Somaetek forest in North Halmahera, Indonesia ( $1^{\circ} 25^{\prime} 22^{\prime \prime}$ LU $127^{\circ} 46^{\prime} 59^{\prime \prime}$ E). The specimen was stored in Bogor Botanical Gardens (specimen number VII.G.237a).

\subsection{Extraction and Isolation}

The dried bark of G. forbesii $(3.5 \mathrm{~kg}$ ) was ground into powder and macerated at room temperature with $\mathrm{CH}_{2} \mathrm{Cl}_{2}(3 \times 15 \mathrm{~L})$ for three days. The solvent was evaporated under reduced pressure to obtain the extract (121 g). The separation was then carried out by VLC with silica gel $(300.0 \mathrm{~g})$ using 100\% v/v $n$-hexane, 100\% v/v methylene chloride, $100 \% v / v$ ethyl acetate, and 100\% v/v methanol to yield four fractions: $n$-hexane (F1: $8.0 \mathrm{~g}$ ); $\mathrm{CH}_{2} \mathrm{Cl}_{2}$ (F2: $46.0 \mathrm{~g}$ ); EtOAc (F3: $43.0 \mathrm{~g}$ ), and $\mathrm{MeOH}$ (F4: $8.0 \mathrm{~g}$ ) fractions. The $\mathrm{CH}_{2} \mathrm{Cl}_{2}$ fraction was separated with VLC on silica gel (250.0 g) using $n$-hexane: $\mathrm{CH}_{2} \mathrm{Cl}_{2}$ gradient (100:0, 95:5, $90: 10,85: 15,75: 25,50: 50,0: 100 \mathrm{v} / \mathrm{v})$ to give five subfractions (M1-M5). The subfraction M1 (1.57 g) was chromatographed on Sephadex LH-20 (100.0 g) eluted with $\mathrm{CH}_{2} \mathrm{Cl}_{2}: \mathrm{MeOH}$ 
$(1: 1 \mathrm{v} / \mathrm{v})$ to produce Compounds $1(33.0 \mathrm{mg})$ and $2(54.0 \mathrm{mg})$. Subfraction M2 $(2.5 \mathrm{~g})$ was separated with sephadex LH-20 (100.0 g) using $\mathrm{CH}_{2} \mathrm{Cl}_{2}: \mathrm{MeOH}(1: 1 \mathrm{v} / \mathrm{v})$ to give compound $4(62.0 \mathrm{mg})$ and compound $5(150.0 \mathrm{mg})$. Compound $3(256.0 \mathrm{mg})$ was obtained from subfraction M3 (3.5 g) separated by repeated chromatography on Sephadex LH-20 (100 g) with $\mathrm{CH}_{2} \mathrm{Cl}_{2}: \mathrm{MeOH}(30: 70 \mathrm{v} / \mathrm{v})$.

\subsubsection{Lichexanthone (1)}

Pale yellow powder; mp: $186-188^{\circ} \mathrm{C}$; UV (MeOH) $\lambda_{\max }$ : 302, 232, and $224 \mathrm{~nm}$; IR $v_{\max }(\mathrm{KBr}): 3446,2918,1639,1608,1452,1280$, and $1207 \mathrm{~cm}^{-1}$, for ${ }^{1} \mathrm{H}\left(400 \mathrm{MHz}, \mathrm{CDCl}_{3}\right)$ and ${ }^{13} \mathrm{C}\left(100 \mathrm{MHz}, \mathrm{CDCl}_{3}\right)$ spectroscopic data, see Table 1; and HRESIMS m/z 287.0943 $[\mathrm{M}+\mathrm{H}]^{+}$(calcd. for $\mathrm{C}_{16} \mathrm{H}_{15} \mathrm{O}_{5}, 287.0919$ ).

Table 1. ${ }^{1} \mathrm{H}\left(400 \mathrm{MHz}\right.$ ) and ${ }^{13} \mathrm{C}$ (100 MHz) NMR of Compounds 1-3 (in ppm).

\begin{tabular}{|c|c|c|c|c|c|c|}
\hline \multirow{2}{*}{ Position } & \multicolumn{2}{|c|}{$1\left(\mathrm{CDCl}_{3}\right)$} & \multicolumn{2}{|c|}{$2\left(\mathrm{DMSO}-d_{6}\right)$} & \multicolumn{2}{|c|}{$3\left(\mathrm{DMSO}-d_{6}\right)$} \\
\hline & $\delta_{\mathrm{H}}(J$ in $\mathrm{Hz})$ & $\delta_{C}$ & $\delta_{H}(J$ in $\mathrm{Hz})$ & $\delta_{C}$ & $\delta_{\mathrm{H}}(J$ in $\mathrm{Hz})$ & $\delta_{C}$ \\
\hline 1 & & 163.9 & & 146.6 & & 151.0 \\
\hline 2 & $6.30, \mathrm{~d}(2.3)$ & 96.8 & & 143.4 & & 127.4 \\
\hline 3 & & 165.9 & $7.26, \mathrm{~s}$ & 125.4 & $7.28, \mathrm{~s}$ & 122.0 \\
\hline 4 & $6.32, \mathrm{~d}(2.3)$ & 92.2 & & 118.8 & & 136.2 \\
\hline $4 a$ & & 157.1 & & 133.7 & & 141.2 \\
\hline $10 \mathrm{a}$ & & 159.5 & & 146.4 & & 144.6 \\
\hline 5 & $6.65, \mathrm{~d}(2.5)$ & 98.6 & & 121.6 & & 146.2 \\
\hline 6 & & 163.8 & & 139.4 & $7.34, \mathrm{~d}(7.0)$ & 120.8 \\
\hline 7 & $6.68, \mathrm{~d}(2.5)$ & 115.6 & & 112.4 & $7.30, \mathrm{t}(7.0)$ & 124.2 \\
\hline 8 & & 143.6 & $7.41, \mathrm{~s}$ & 113.8 & $7.60, \mathrm{~d}(7.0)$ & 114.8 \\
\hline $8 a$ & & 128.0 & & 114.8 & & 120.5 \\
\hline 9 & & 182.5 & & 182.4 & & 182.7 \\
\hline $9 a$ & & 104.2 & & 109.1 & & 108.1 \\
\hline $1^{\prime}$ & & & $5.91, \mathrm{~d}(10.0)$ & 122.6 & & \\
\hline $2^{\prime}$ & & & $6.59, \mathrm{~d}(10.0)$ & 132.5 & & \\
\hline $3^{\prime}$ & & & & 79.5 & & \\
\hline $4^{\prime}$ & & & $1.58, \mathrm{~s}$ & 28.4 & & \\
\hline $5^{\prime \prime}$ & & & $1.58, \mathrm{~s}$ & 28.4 & & \\
\hline $1^{\prime \prime}$ & & & & 110.7 & & 98.4 \\
\hline $2^{\prime \prime}$ & & & $6.31, \mathrm{dd}(17.5,10.6)$ & 147.1 & $6.23, \mathrm{dd}(17.8,10.3)$ & 146.6 \\
\hline $3^{\prime \prime}$ & & & $\begin{array}{l}\text { 5.10, d (17.5) } \\
5.01, \mathrm{~d}(10.6)\end{array}$ & 111.2 & $\begin{array}{l}\text { 5.01, d (17.8) } \\
4.97, \mathrm{~d}(10.3)\end{array}$ & 110.7 \\
\hline $4^{\prime \prime}$ & & & $1.46, \mathrm{~s}$ & 27.4 & $1.47, \mathrm{~s}$ & 26.3 \\
\hline $5^{\prime \prime}$ & & & $1.46, \mathrm{~s}$ & 27.4 & $1.47, \mathrm{~s}$ & 26.3 \\
\hline $1-\mathrm{OH}$ & $13.69, \mathrm{~s}$ & & $12.84, \mathrm{~s}$ & & $12.75, \mathrm{~s}$ & \\
\hline $2-\mathrm{OH}$ & & & $9.41, \mathrm{~s}$ & & & \\
\hline $4-\mathrm{OH}$ & & & & & $10.15, \mathrm{~s}$ & \\
\hline $5-\mathrm{OH}$ & & & $9.16, \mathrm{~s}$ & & $9.30, \mathrm{~s}$ & \\
\hline 3-OMe & $4.20 \mathrm{~s}$ & 55.8 & & & & \\
\hline 6-OMe & $4.18 \mathrm{~s}$ & 55.9 & & & & \\
\hline $8-\mathrm{CH}_{3}$ & $3.15, \mathrm{~s}$ & 23.6 & & & & \\
\hline
\end{tabular}

Note: s: singlet; d: douplet; t: triplet; dd: doublet of doublet.

\subsubsection{Subelliptenone $\mathrm{H}(2)$}

Yellow powder; mp: $175-177^{\circ} \mathrm{C}$; UV (MeOH) $\lambda_{\max }$ : 352, 294, and $208 \mathrm{~nm}$; IR $v_{\max }$ (KBr): 3441, 2974, 1641, 1585, 1471, 1288, and $1207 \mathrm{~cm}^{-1}$, for ${ }^{1} \mathrm{H}\left(400 \mathrm{MHz}, \mathrm{DMSO}-d_{6}\right)$ and ${ }^{13} \mathrm{C}\left(100 \mathrm{MHz}, \mathrm{DMSO}-d_{6}\right)$ spectroscopic data, see Table 1 ; and HRESIMS $m / z 395.1506$ $[\mathrm{M}+\mathrm{H}]^{+}$(calcd. for $\left.\mathrm{C}_{23} \mathrm{H}_{23} \mathrm{O}_{6}, 395.1495\right)$. 


\subsubsection{2b-Hydroxy-des-D-garcigerrin A (3)}

Yellow powder; mp: $207-209^{\circ} \mathrm{C}$; UV (MeOH) $\lambda_{\max }$ : 310, 246, and $206 \mathrm{~nm}$; IR $v_{\max }$ (KBr): $3325,2964,1639,1583,1462,1234$, and $1178 \mathrm{~cm}^{-1}$, for ${ }^{1} \mathrm{H}\left(400 \mathrm{MHz}, \mathrm{DMSO}-d_{6}\right)$ and ${ }^{13} \mathrm{C}\left(100 \mathrm{MHz}\right.$, DMSO- $\left.d_{6}\right)$ spectroscopic data, see Table 1; and HRESIMS $\mathrm{m} / z 335.0920$ $[\mathrm{M}+\mathrm{Na}]^{+}$(calcd. for $\mathrm{C}_{18} \mathrm{H}_{18} \mathrm{O}_{5} \mathrm{Na}, 335.0895$ ).

\subsubsection{Garciniaxanthone B (4)}

Yellow powder; mp: $167-169^{\circ} \mathrm{C}$; UV $(\mathrm{MeOH}) \lambda_{\max }: 342,262$, and $206 \mathrm{~nm}$; IR $v_{\max }$ (KBr): $3527,2976,1637,1618,1450,1290$, and $1182 \mathrm{~cm}^{-1}$, for ${ }^{1} \mathrm{H}\left(400 \mathrm{MHz}, \mathrm{DMSO}-d_{6}\right)$ and ${ }^{13} \mathrm{C}\left(100 \mathrm{MHz}\right.$, DMSO- $\left.d_{6}\right)$ spectroscopic data, see Table 2; and HRESIMS $m / z 379.1558$ $[\mathrm{M}+\mathrm{H}]^{+}$(calcd. for $\mathrm{C}_{23} \mathrm{H}_{23} \mathrm{O}_{5}, 379.1545$ ).

Table 2. ${ }^{1} \mathrm{H}(400 \mathrm{MHz})$ and ${ }^{13} \mathrm{C}(100 \mathrm{MHz}) \mathrm{NMR}$ of Compounds 4-5 (in ppm).

\begin{tabular}{|c|c|c|c|c|}
\hline \multirow{2}{*}{ Position } & \multicolumn{2}{|c|}{$4\left(\mathrm{DMSO}-d_{6}\right)$} & \multicolumn{2}{|c|}{$5\left(\mathrm{DMSO}-d_{6}\right)$} \\
\hline & $\delta_{\mathrm{H}}(J$ in $\mathrm{Hz})$ & $\delta_{C}$ & $\delta_{\mathrm{H}}(J$ in $\mathrm{Hz})$ & $\delta_{C}$ \\
\hline 1 & & 151.1 & & 151.2 \\
\hline 2 & & 126.6 & & 122.7 \\
\hline 3 & $7.35, \mathrm{~s}$ & 122.6 & $7.33, \mathrm{~s}$ & 122.5 \\
\hline 4 & & 136.3 & & 136.3 \\
\hline $4 a$ & & 140.6 & & 141.8 \\
\hline $10 \mathrm{a}$ & & 144.9 & & 141.1 \\
\hline 5 & & 141.9 & & 147.5 \\
\hline 6 & & 127.3 & & 137.9 \\
\hline 7 & $7.20, \mathrm{~d}(8.0)$ & 121.3 & $7.37, \mathrm{~d}(8.0)$ & 120.6 \\
\hline 8 & 7.66, d (8.0) & 116.4 & $7.69, \mathrm{~d}(8.0)$ & 117.0 \\
\hline $8 a$ & & 121.7 & & 108.6 \\
\hline 9 & & 182.3 & & 182.5 \\
\hline $9 a$ & & 108.5 & & 120.7 \\
\hline $1^{\prime}$ & $6.05, \mathrm{~d}(10.0)$ & 120.2 & $5.38, \mathrm{~d}(4.7)$ & 71.8 \\
\hline $2^{\prime}$ & $6.60, \mathrm{~d}(10.0)$ & 134.5 & $4.36, \mathrm{~d}(4.7)$ & 98.3 \\
\hline $3^{\prime}$ & & 77.7 & & 69.7 \\
\hline $4^{\prime}$ & $1.48, \mathrm{~s}$ & 27.7 & $1.22, \mathrm{~s}$ & 25.8 \\
\hline $5^{\prime}$ & $1.48, \mathrm{~s}$ & 27.7 & $1.20, \mathrm{~s}$ & 25.4 \\
\hline $1^{\prime \prime}$ & & 99.5 & & 85.7 \\
\hline $2^{\prime \prime}$ & $6.25, \mathrm{dd}(17.9,10.2)$ & 146.7 & $6.21, \mathrm{dd}(17.6,10.5)$ & 146.7 \\
\hline $3^{\prime \prime}$ & 5.01, d (17.9) & 110.8 & $4.98, \mathrm{~d}(17.6)$ & 110.8 \\
\hline $4^{\prime \prime}$ & 4.99, d (10.2) & 263 & 4.98, d (10.5) & 263 \\
\hline $\begin{array}{l}4 \\
5^{\prime \prime}\end{array}$ & $\begin{array}{l}1.58, \mathrm{~s} \\
1.58, \mathrm{~s}\end{array}$ & $\begin{array}{l}20.3 \\
26.3\end{array}$ & $\begin{array}{l}1.43, \mathrm{~s} \\
1.45, \mathrm{~s}\end{array}$ & $\begin{array}{l}26.3 \\
26.3\end{array}$ \\
\hline $1-\mathrm{OH}$ & $12.91, \mathrm{~s}$ & & $12,87, \mathrm{~s}$ & \\
\hline $4-\mathrm{OH}$ & $9.49, \mathrm{~s}$ & & $9.57, \mathrm{~s}$ & \\
\hline $1^{\prime}-\mathrm{OH}$ & & & $6.00, \mathrm{~s}$ & \\
\hline $2^{\prime}-\mathrm{OH}$ & & & $4.73, \mathrm{~s}$ & \\
\hline
\end{tabular}

Note: s: singlet; d: douplet; t: triplet; dd: doublet of doublet.

\subsubsection{Garcigerin A (5)}

Yellow powder; mp: $246-248{ }^{\circ} \mathrm{C}$; UV (MeOH) $\lambda_{\max }$ : 398, 314, 250 and $206 \mathrm{~nm}$; IR $v_{\max }(\mathrm{KBr}): 3423,2978,1637,1608,1464,1230$, and $1165 \mathrm{~cm}^{-1}$, for ${ }^{1} \mathrm{H}\left(400 \mathrm{MHz}\right.$, DMSO- $\left.d_{6}\right)$ and ${ }^{13} \mathrm{C}\left(100 \mathrm{MHz}\right.$, DMSO- $\left.d_{6}\right)$ spectroscopic data, see Table 2; and HRESIMS $\mathrm{m} / \mathrm{z} 435.1437$ $[\mathrm{M}+\mathrm{Na}]^{+}$(calcd. For $\mathrm{C}_{23} \mathrm{H}_{24} \mathrm{O}_{7} \mathrm{Na}, 435.1420$ ). 


\subsection{Antioxidant Assay}

\subsubsection{DPPH Radical Scavenging Assay}

DPPH (1,1-diphenyl-2-picrylhydrazyl) was used for the antioxidant test using quercetin and gallic acid as controls. The compounds were diluted at concentrations of 159.73, 79.87, $39.93,19.97,9.98 \mu \mathrm{g} / \mathrm{mL}$. A total $1 \mathrm{~mL}$ of DPPH $6 \times 10^{-5} \mathrm{M}$ solution, complete with $33 \mu \mathrm{L}$ of the compound, was incubated at $37^{\circ} \mathrm{C}$ for $20 \mathrm{~min}$. The experiment was carried out with three replications and the absorbance was observed at a wavelength of $517 \mathrm{~nm}$. The radical inhibitory activity was calculated using the equation $[(\mathrm{Ab}-\mathrm{As}) / \mathrm{Ab}] \times 100 \%$.

\subsubsection{ABTS Radical Scavenging Assay}

The antioxidant activity was also determined by free radical ABTS $\left(2,2^{\prime \prime}\right.$-azinobis (3-ethyl benzothiazoline-6-sulfonic acid) according to the reported procedure [12]. In this test, $7 \mathrm{mM}$ ABTS solution was prepared and mixed with a buffer solution of potassium peroxydisulfate, incubated for $16 \mathrm{~h}$, and protected from light. A total of $10 \mu \mathrm{L}$ of the sample and $1 \mathrm{~mL}$ of the ABTS was incubated for $4 \mathrm{~min}$ and measured at a wavelength of $734 \mathrm{~nm}$. This experiment was performed triplo using quercetin and gallic acid as controls. The ABTS inhibitory activity was calculated by the equation $[(\mathrm{Ab}-\mathrm{As}) / \mathrm{Ab}] \times 100 \%$.

\subsubsection{Ferric Reducing-Antioxidant Power (FRAP) Assay}

The FRAP assay was determined according to the described method [13] using $300 \mathrm{mM}$ acetate buffer, $40 \mathrm{mM} \mathrm{HCl}, 10 \mathrm{mM}$ (2,4,6 Tris(2-pyridyl)-s-triazine (TPTZ)), $20 \mathrm{mM}$ $\mathrm{FeCl}_{3} \cdot 6 \mathrm{H}_{2} \mathrm{O}$. For standard curve comparison, a 10:1:1 (acetate buffer: TPTZ: $\mathrm{H}_{2} \mathrm{O}$ ) and sample ratio 10:1:1 (acetate buffer: TPTZ: $\mathrm{FeCl}_{3} \cdot 6 \mathrm{H}_{2} \mathrm{O}$ ) were constructed. The standard curve was prepared using various concentrations of $\mathrm{FeSO}_{4} \cdot 7 \mathrm{H}_{2} \mathrm{O}$. The reaction mixture was incubated at $37^{\circ} \mathrm{C}$ for $30 \mathrm{~min}$ followed by measurement of the absorbance at $593 \mathrm{~nm}$. In this test, the reduction capacity of the tested compound calculated concerning the reaction signal given by the $\mathrm{Fe}^{2+}$ solution. The FRAP value was expressed as $\mu \mathrm{M} \mathrm{Fe}^{2+} / \mathrm{g}$ ((Frap value of sample $(\mu \mathrm{M})=$ abs $($ sample $) \times$ FRAP value of std $(\mu \mathrm{M}) /$ abs $($ std $)$.

\subsection{In Vitro Antidiabetic Assay}

\subsubsection{Rat Intestinal $\alpha$-glucosidase Inhibitory Activity}

The inhibitory activity of rat intestinal $\alpha$-glucosidase was determined according to previously reported method [14] with slight modifications. This procedure was performed by classifying four mixtures in different groups. The mixture (1) labelled "Blank of enzyme reaction" contained the mixture and DMSO $(10 \mu \mathrm{L})$, sodium phosphate buffer $(50 \mu \mathrm{L})$, glucose kit $(80 \mu \mathrm{L})$, enzyme $(20 \mu \mathrm{L})$ and substrate $(20 \mu \mathrm{L}$ maltose, sucrose $20 \mu \mathrm{L})$. A $10 \mu \mathrm{L}$ of sample and samples with various concentrations of compounds was added to the well Plates (3) and (4). A $50 \mu \mathrm{L}$ of sodium phosphate buffer ( $\mathrm{pH}$ 6.9) was then added to well Plates (1) and (3), and a $30 \mu \mathrm{L}$ of the buffer was added to well Plates (2) and (4), respectively. The substrate (maltose, $20 \mu \mathrm{L}$; sucrose $20 \mu \mathrm{L}$ ) was then added to the Plates (2) and (4). A glucose kit $(80 \mu \mathrm{L}$ each) and the enzyme $(20 \mu \mathrm{L})$ were added to all plates and were incubated for $10 \mathrm{~min}$ for maltose and $40 \mathrm{~min}$ for sucrose. Finally, the absorbance was then measured at $\lambda=520 \mathrm{~nm}$ using a microplate reader (BioTek ELx800TM, BioTek Instruments, Inc., Winooski, VT, USA).

\subsection{2. $\alpha$-Amylase Inhibitory Activity}

The modified $\alpha$-amylase enzyme inhibition test was conducted for antidiabetic activity evaluation [15]. A total of $10 \mathrm{mg}$ sample was dissolved in $1 \mathrm{~mL}$ DMSO and $0.1 \mathrm{M}$ phosphate buffer and $5 \mathrm{mg} \alpha$-amylase solution (Porcine pancreatic $\alpha$-amylase) in $1 \mathrm{~mL}$ phosphate buffer $\mathrm{pH} 6.9$ was added. A $100 \mathrm{mg}$ of potato starch (substrate) was heated in $5 \mathrm{~mL}$ of $0.1 \mathrm{M}$ phosphate buffer for $5 \mathrm{~min}$ and cooled to room temperature. Then, $20 \mu \mathrm{L}$ of the sample and $50 \mu \mathrm{L}$ of substrate were mixed into $30 \mu \mathrm{L}$ of phosphate buffer. The mixture was pre-incubated for $5 \mathrm{~min}$ followed by the addition of $20 \mu \mathrm{L}$ of $\alpha$-amylase enzyme and then incubation at $37^{\circ} \mathrm{C}$ for $15 \mathrm{~min}$. The color development was performed by adding $50 \mu \mathrm{L}$ 
of $1 \mathrm{M} \mathrm{HCl}$ and $50 \mu \mathrm{L}$ of $10 \%$ iodine solution. Finally, the absorbance was measured at a wavelength of $650 \mathrm{~nm}$.

\subsection{In Vitro Antiplasmodial Assay}

The antiplasmodial activity was carried out by the described procedure [16,17] using P. falciparum strain 3D7 sensitive to chloroquine (the LDH method). The samples were made with concentrations of 50, 10,5, 1, 0.5, 0.1, 0.05, and $0.01 \mu \mathrm{g} / \mathrm{mL}$. The parasites used in this test were synchronized (Ring stage) with $\pm 0.3 \%$ parasitemia ( $2 \%$ hematocrit). A total of $1 \mu \mathrm{L}$ of the test solution with various concentrations was taken in to each well (well 96) and then added $99 \mu \mathrm{L}$ with parasites (each concentration repeated three times). The well plates were put in the chamber with mix gas atmosphere $\left(\mathrm{O}_{2} 5 \%, \mathrm{CO}_{2} 5 \%\right.$ and $\left.\mathrm{N}_{2} 90 \%\right)$ and incubated for $72 \mathrm{~h}$ at $37^{\circ} \mathrm{C}$. After that, the plate was harvested and stored at $-30{ }^{\circ} \mathrm{C}$. After $24 \mathrm{~h}$, the $p \mathrm{LDH}$ assay was performed by reading the absorbance at $650 \mathrm{~nm}$ using a SpectraMax Paradigm ${ }^{\circledR}$ Multi-Mode microplate reader.

\subsection{In Silico Molecular Docking Studies and ADMET Prediction}

The 2-D structures of compounds 1-5 were drawn using ChemDraw 18.0 and converted to the 3-D. Their minimum energy was calculated using Chem 3D 18.0 and then stored as mol2. \{SYBYL2 (*. Mol2)\} format. The crystal structure of human lysosomal acidalpha-glucosidase (PDB ID: 5NN8) and P. falciparum lactate dehydrogenase enzyme (PDB ID: 1CET) with the ligands acarbose and chloroquine was retrieved from the Protein Data Bank. The docking results were expressed as mol dock score (MDS), the energy required in the ligand-receptor interaction, and based on these values, the antidiabetic or antiplasmodial activity of the compounds were predicted. The ADMET properties of the most active compound were calculated by using ProTox Online Tool (http:/ / scistore.cambridgesoft. com, accessed on 5 May 2021), Open babel GUI 2.4.1 (https:/ / sourceforge.net, accessed 25 May 2021), Toxtree version 2.6.6 (http:/ / toxtree.sourceforge.net, accessed on 13 June 2021), pkCSM (http: / / biosig.unimelb.edu.au/pkcsm, accessed on 21 June 2021), and preADMET (http:/ / preadmet.bmdrs.kr, accessed on 3 July 2021).

\subsection{Statistical Analysis}

The study was conducted three times to determine the mean value (mean SD). A linear regression equation was generated for determination of the percentage of $\alpha$-glucosidase and $\alpha$-amylase inhibition concentration of each compound. The difference measured to be statistically significant when the $p$-value $<0.05$.

\section{Results and Discussion}

\subsection{Structure Elucidation}

The phytochemical investigation of $\mathrm{CH}_{2} \mathrm{Cl}_{2}$ extract of the bark of $\mathrm{G}$. forbesii produced five xanthones namely lichexanthone (1) [18,19], subelliptenone $H$ (2) [20], 12b-hydroxy-desD-garcigerrin A (3) [21,22], garciniaxanthone B (4) [23] and garcigerin A (5) [24]. All isolated compounds were elucidated by spectroscopic methods including NMR and HRESIMS analysis, and literature data comparison. To the best of our knowledge, this is the first report of the known compounds 1-5 from G. forbesii (Figure 1). 
<smiles>COc1cc(C)c2c(=O)c3c(O)cc(OC)cc3oc2c1</smiles>

1<smiles></smiles><smiles>[C-]=CC(F)(F)c1cc(O)c2oc3c(O)cccc3c(=O)c2c1O</smiles>

3<smiles>C=CC(C)(C)c1cc(O)c2oc3c4c(ccc3c(=O)c2c1O)C=CC(C)(C)O4</smiles>

4<smiles>C=CC(C)(C)c1cc(O)c2oc3c4c(ccc3c(=O)c2c1O)[C@@H](O)[C@H](O)C(C)(C)O4</smiles>

5

Figure 1. The isolated compounds (1-5) from the stem barks of G. forbesii.

\subsection{Antioxidant Activity}

The antioxidant activity depends on the existence of hydroxyl groups and substituents on the aromatic ring. The antioxidant activity of phenolic compounds is well known to be related to the presence of ortho- and para-substituted hydroxyl groups on the aromatic ring and carbonyl groups as well [25]. The antioxidant activity of isolated xanthones 1-5 was assayed by DPPH, ABTS and FRAP methods. DPPH is known for its stability and free radicals scavenging activity [26]. A radical species containing nitrogen atoms of ABTS stabilizes the free radicals through proton donors [27]. The ABTS assay can be applied to lipophilic and hydrophilic compounds [28]. Furthermore, the iron reductive properties of compounds which is an important part of antioxidant activity can be evaluated by using FRAP method [29].

The free radical scavenging power based on DPPH test with quercetin and gallic acid as standards indicated that the inhibitory concentration $50 \%\left(\mathrm{IC}_{50}\right)$ of compounds $\mathbf{2}-\mathbf{5}$ was ranging from 14.1 to $20.4 \mu \mathrm{M}$ at a concentration of $159.7 \mu \mathrm{g} / \mathrm{mL}$ (Table 3). Compound 1 was inactive with inhibition below 50\%. Previously reported garcinoxanthones SV, garcinone E, and 1,3,6,7-tetrahydroxyxanthone from G. mangostana L. showed significant DPPH scavenging capacity with $\mathrm{IC}_{50}$ values of $68.55,63.05$, and $28.45 \mu \mathrm{M}$, respectively, compared to ascorbic acid $\left(\mathrm{IC}_{50}=48.03 \mu \mathrm{M}\right)$. The hydroxyl position of groups gave significant impact on the antioxidant activity of the latter compound [30]. The ABTS antioxidant activity of compounds $\mathbf{2}-\mathbf{5}$ was significant with $\mathrm{IC}_{50}$ values ranging from $0.05-7.9 \mu \mathrm{M}$ (Table 3 ). Compound 1 showed no significant activity with low inhibition at $99 \mu \mathrm{g} / \mathrm{mL}(<50 \%)$. In particular, compound 3 was found to be the most potent with $\mathrm{IC}_{50}$ value 4 -fold lower than quercetin. Other compounds with xanthone skeleton such as $\alpha$-mangostin and $\gamma$-mangostin isolated from G. mangostana L. showed high activity in ABTS radical scavenging [31]. In addition, the antioxidant evaluation of compounds 1-5 using FRAP test, as shown in Table 3, demonstrated that the reduction power of compound 3 was found to be the highest one with value of $203.9 \pm 1.19 \mu \mathrm{M} \mathrm{Fe}^{2+} / \mathrm{g}$. This activity was followed by compounds 4,5 , and 2 with values of $192.7,187.8$, and $166.3 \mu \mathrm{M} \mathrm{Fe}^{2+} / \mathrm{g}$, respectively. The iron reducing power of compound 3 was approximately 6 -fold greater than ascorbic acid as standard $(30.6 \mu \mathrm{M}$ $\mathrm{Fe}^{2+} / \mathrm{g}$ ). These results implied that compounds $\mathbf{2}-\mathbf{5}$ are potent antioxidant compounds. The reducing power of other xanthones with carbonyl group and halogen substituents, i.e., (R)-6-chloro-2-\{[(1-hydroxypropan-2-yl)(methyl)amino]-methyl\}-9H-xanthen-9-one hy- 
drochloride and ( $R, S)$-2-chloro-7-\{[(1-hydroxybutan-2-yl)amino]methyl\}-9H-xanthen-9-one synthesis results are reported better than vitamin $C$ [32].

Table 3. Antioxidant activity of compounds $\mathbf{1}-\mathbf{5}$.

\begin{tabular}{|c|c|c|c|c|c|}
\hline \multirow{3}{*}{ Compounds } & \multicolumn{5}{|c|}{ Antioxidant Activity } \\
\hline & \multirow{2}{*}{$\begin{array}{c}\text { FRAP } \\
\mu \mathrm{M} \mathrm{Fe}^{2+} / \mathrm{g}\end{array}$} & \multicolumn{2}{|c|}{ DPPH } & \multicolumn{2}{|c|}{ ABTS } \\
\hline & & $\begin{array}{c}\text { \% Inhibition } \\
(159.7 \mu \mathrm{g} / \mathrm{mL})\end{array}$ & $\mathrm{IC}_{50}(\mu \mathrm{M})$ & $\begin{array}{c}\text { \% Inhibition } \\
(99 \mu \mathrm{g} / \mathrm{mL})\end{array}$ & $\mathrm{IC}_{50}(\mu \mathrm{M})$ \\
\hline 1 & $5.7 \pm 0.57$ & $41.60 \pm 0.02$ & $>1000$ & $33.24 \pm 0.01$ & $>1000$ \\
\hline 2 & $166.3 \pm 1.47$ & $95.29 \pm 0.05$ & $19.4 \pm 0.15$ & $97.29 \pm 0.04$ & $2.7 \pm 0.05$ \\
\hline 3 & $203.9 \pm 1.19$ & $96.83 \pm 0.03$ & $18.9 \pm 0.10$ & $98.31 \pm 0.05$ & $0.05 \pm 0.01$ \\
\hline 4 & $192.7 \pm 0.77$ & $95.38 \pm 0.08$ & $14.1 \pm 0.07$ & $96.15 \pm 0.01$ & $7.9 \pm 0.01$ \\
\hline 5 & $187.8 \pm 1.36$ & $96.60 \pm 0.05$ & $20.4 \pm 0.22$ & $97.40 \pm 0.03$ & $6.5 \pm 0.02$ \\
\hline Ascorbic acid & $30.6 \pm 0.27$ & $\mathrm{Nt}$ & $\mathrm{Nt}$ & $\mathrm{Nt}$ & $\mathrm{Nt}$ \\
\hline Quercetin & $\mathrm{Nt}$ & $96.34 \pm 0.01$ & $4.1 \pm 0.01$ & $97.58 \pm 0.01$ & $0.17 \pm 0.01$ \\
\hline Gallic acid & $\mathrm{Nt}$ & $97.21 \pm 0.01$ & $3.0 \pm 0.01$ & $96.30 \pm 0.01$ & $0.7 \pm 0.01$ \\
\hline
\end{tabular}

Note: $\mathrm{IC}_{50}>1000 \mu \mathrm{M}=$ inactive, $\mathrm{Nt}=$ not tested.

The antioxidant evaluation of isolated compounds 1-5 argued that the presence of dimethylallyl moiety and additional hydroxy groups on the structures of $\mathbf{2}-\mathbf{5}$ was assumed to play important roles in enhancing the antioxidant capacity. Notably, the lack of pyran ring in 3 gave a potent ABTS scavenging activity with $\mathrm{IC}_{50}$ value lower than the standards quercetin and gallic acid.

\subsection{In Vitro Antidiabetic Assay}

The antidiabetic potential of compounds $\mathbf{1 - 5}$ was evaluated on $\alpha$-glucosidase and $\alpha$-amylase enzymes. The $\alpha$-glucosidase inhibitory activity of the five tested compounds was performed using sucrose and maltose as the substrates, and acarbose as the positive control [33]. The $\alpha$-glucosidase is known to break the 1,4- $\alpha$ bond of carbohydrate into its monomers such as glucose and fructose [34]. The results of $\alpha$-glucosidase assay, as shown in Table 4, showed that compound 5 was the most potent compound with $\mathrm{IC}_{50}$ value of $37.4 \mu \mathrm{M}$ followed by compounds 2,4 , and 3 using sucrose as substrate. In contrast, only compounds 2 and 5 inhibited the enzyme activity with $\mathrm{IC}_{50}$ values lower than $100 \mu \mathrm{M}$ using maltose as substrate. Compound 1 was inactive in both substrates. A new xanthone namely subelliptenone $F$ had a significant effect on $\alpha$-glucosidase with an $\mathrm{IC}_{50}$ value of $4.1 \mu \mathrm{M}$ compared to acarbose $\left(\mathrm{IC}_{50}=900.0 \mu \mathrm{M}\right)[9]$.

Table 4. The in vitro antidiabetic activity of Compounds 1-5.

\begin{tabular}{cccc}
\hline \multirow{2}{*}{ Compounds } & \multicolumn{2}{c}{$\boldsymbol{\alpha - G l u c o s i d a s e}$} & $\alpha$-Amylase \\
\cline { 2 - 4 } & $\begin{array}{c}\text { Sucrose } \\
\mathbf{I C}_{\mathbf{5 0}}(\boldsymbol{\mu M})\end{array}$ & $\begin{array}{c}\text { Maltose } \\
\mathbf{I C}_{\mathbf{5 0}}(\boldsymbol{\mu} \mathbf{M})\end{array}$ & $\begin{array}{c}\text { Starch } \\
\mathbf{I C}_{\mathbf{5 0}}(\boldsymbol{\mu M} \mathbf{M})\end{array}$ \\
\hline $\mathbf{1}$ & $>1000$ & $>1000$ & $>1000$ \\
$\mathbf{2}$ & $43.8 \pm 1.51$ & $49.3 \pm 0.14$ & $41.3 \pm 1.24$ \\
$\mathbf{3}$ & $79.6 \pm 2.01$ & $109.0 \pm 1.31$ & $28.7 \pm 0.35$ \\
$\mathbf{4}$ & $75.9 \pm 2.11$ & $139.4 \pm 1.21$ & $10.8 \pm 0.04$ \\
$\mathbf{5}$ & $37.4 \pm 1.20$ & $91.0 \pm 1.14$ & $18.7 \pm 0.54$ \\
Acarbose & $4.6 \pm 0.51$ & $3.4 \pm 0.27$ & $4.0 \pm 0.32$ \\
\hline
\end{tabular}

Note: $\mathrm{IC}_{50}>1000 \mu \mathrm{M}=$ inactive.

$\alpha$-Amylase is one of the key enzymes responsible for degrading starch to glucose in the human body $[35,36]$. The inhibitory activity of the tested compounds on $\alpha$-amylase enzyme indicated that all compounds, except compound 1, were active with $\mathrm{IC}_{50}$ values of 
$10.8-41.3 \mu \mathrm{M}$. The highest activity was shown by compound 4 with $\mathrm{IC}_{50}$ value $10.8 \mu \mathrm{M}$. It is noted that compounds $\mathbf{2}-\mathbf{5}$ are active as $\alpha$-glucosidase and $\alpha$-amylase inhibitors. This activity was supposed to be influenced by the dimethylallyl group and pyran rings in the xanthone structure. Compound 1 without dimethylallyl group and pyran rings was not active. The antidiabetic trend of compounds 1-5 was similar with the antioxidant inhibition pattern.

\subsection{In Vitro Antiplasmodial Assay}

The in vitro antiplasmodial activity of compounds 1-5 against $P$. falciparum strain 3D7 was assessed by lactate dehydrogenase of P. falciparum (pLDH) assay [37]. Table 5 displayed that Compounds 2 and 3 were active against $P$. falciparum strain 3D7 with inhibition percentage of $86.8 \pm 0.3 \%\left(\mathrm{IC}_{50} 3.3 \pm 0.04 \mu \mathrm{M}\right)$ and $87.9 \pm 0.2 \%\left(\mathrm{IC}_{50} 5.0 \pm 0.04 \mu \mathrm{M}\right)$ at a concentration of $10 \mu \mathrm{g} / \mathrm{mL}$. Compounds 1, 4, and 5 were not active due to their inhibitory activity below $10 \%$. The standard chloroquine showed $98.8 \pm 0.25 \%$ inhibition and $\mathrm{IC}_{50}$ value of $0.006 \pm 0.01 \mu \mathrm{M}$. These results implied that compounds 2 and 3 are potent as antimalarial agents against the P. falciparum 3D7 strain [38]. New xanthones Mckeanianones A, B, C, D, E from G. mckeaniana possessing a pyrano ring and two isoprene units also exhibited antimalarial activity against $P$. falciparum strains, TM4 and K1, and cytotoxic activity against the Vero cell line [7].

Table 5. The in vitro antiplasmodial activity of compounds 1-5.

\begin{tabular}{ccc}
\hline Compounds & \% Inhibition $(\mathbf{1 0} \boldsymbol{\mu g} / \mathbf{m L})$ & IC $_{\mathbf{5 0}}(\boldsymbol{\mu M})$ \\
\hline $\mathbf{1}$ & $<10$ & $\mathrm{Nt}$ \\
$\mathbf{2}$ & $86.8 \pm 0.33$ & $3.3 \pm 0.04$ \\
$\mathbf{3}$ & $87.9 \pm 0.23$ & $5.0 \pm 0.04$ \\
$\mathbf{4}$ & $<10$ & $\mathrm{Nt}$ \\
$\mathbf{5}$ & $<10$ & $\mathrm{Nt}$ \\
Chloroquine & $98.8 \pm 0.25$ & $0.006 \pm 0.01$ \\
\hline
\end{tabular}

Note: \% inhibition $<10 \mu \mathrm{g} / \mathrm{mL}=$ inactive, $\mathrm{Nt}=$ not tested.

\subsection{Molecular Docking Studies}

3.5.1. Human Lysosomal Acid- $\alpha$-glucosidase Enzyme (PDB ID: 5NN8)

$\alpha$-Glucosidase is an essential enzyme for sugar metabolism in human body [39]. In this study, the molecular docking of isolated xanthones $\mathbf{2}$ and $\mathbf{5}$ was studied against human lysosomal acid-alpha-glucosidase enzyme (PDB ID: 5NN8) by Molegro Virtual Docker 5.5 compared to acarbose. Interaction analysis indicated that acarbose associates through hydrogen bonding with the residues Arg404(2); Arg600; Asp616(2); Ser676(2); Ser679; Nya674; Leu678; Gly651 and steric interactions at residue sites of Asp616(3); Asp518; Leu678(3); Trp481(2); Trp618(2); Phe649; Gly651.

The docking results indicated that the total energy and MDS of compound 2 were $108.388 \mathrm{kcal} / \mathrm{mol}$ and $-78.81 \mathrm{kcal} / \mathrm{mol}$, and $144.003 \mathrm{kcal} / \mathrm{mol}$ and $-74.54 \mathrm{kcal} / \mathrm{mol}$ for Compound 5 (Table 6). The binding mode of these compounds, as shown in Table 6 and Figure 2, revealed that compounds 2 and 5 inhibit the acid-alpha-glucosidase through hydrogen bonding and steric interaction. These compounds are bound to the active site of human lysosomal acid-alpha-glucosidase enzyme (5NN8) through hydrogen-bonding interaction of carbonyl, chelate hydroxyl, and free hydroxyl groups with Arg600, Asp518, and Asp404 residues. The steric interaction of compound 2 was formed by the oxygen atom of a carbonyl group with Met519 residue, xanthone backbone and the pyran ring with Asp282(2) and Phe649 residues, and the dimethylallyl group with Trp376 residue. The similar interaction was also formed by compound 5 with Asp282 (2), Asp518, Asp616, Trp613 (2), Trp516, Trp376, Phe649, Met519, and His674 residues. 
Table 6. The total energy, MDS, and interacting residues of 2 and 5 to human lysosomal acid-alpha-glucosidase enzyme (5NN8).

\begin{tabular}{|c|c|c|c|c|}
\hline Ligands & $\begin{array}{c}\text { Total Energy } \\
\text { (kcal/mol) }\end{array}$ & $\begin{array}{l}\text { Mol Dock Score } \\
\text { (kcal/mol) }\end{array}$ & Hydrogen Bonding & Steric Interaction \\
\hline 2 & 108.388 & -78.81 & Arg600; Asp518; Asp404 & $\begin{array}{c}\text { Arg600; Phe469(2); } \\
\text { Asp518; Trp376 } \\
\text { Asp282 (2); Asp518; }\end{array}$ \\
\hline 5 & 144.003 & -74.54 & Arg600(3); Asp518 & $\begin{array}{c}\text { Asp616; Trp613 (2); } \\
\text { Trp516; Trp376; Phe649; } \\
\text { Met519; His674 }\end{array}$ \\
\hline Acarbose & 330.989 & -107.31 & $\begin{array}{c}\text { Arg404(2); Arg600; Asp616(2); } \\
\text { Ser676(2); Ser679; His674; } \\
\text { Leu678; Gly651 }\end{array}$ & $\begin{array}{c}\text { Asp616(3); Asp518; } \\
\text { Leu678(3); Trp481(2); } \\
\text { Trp618(2); Phe649; Gly651 }\end{array}$ \\
\hline
\end{tabular}
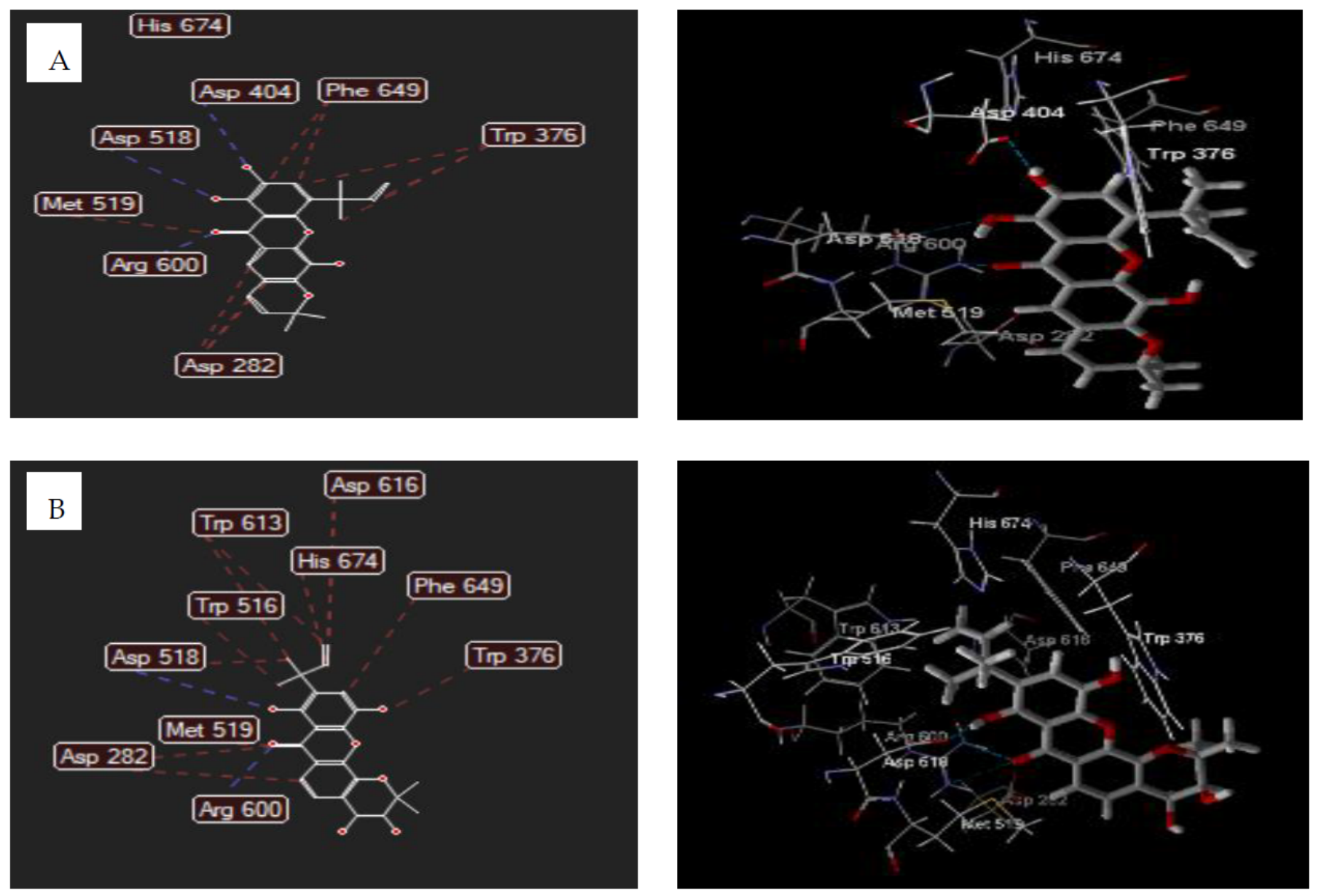

Figure 2. The 2D and 3D interaction of $2(\mathbf{A})$ and $\mathbf{5}(\mathbf{B})$ with human lysosomal acid-alpha-glucosidase enzyme. Hydrogen bonds were depicted as blue dotted lines while steric interactions were shown as red lines. Carbon atoms were represented in gray, oxygen in red and hydrogen in white.

\subsubsection{Plasmodium falciparum Lactate Dehydrogenase Enzyme (PDB ID: 1CET)}

The molecular docking of Xanthones $\mathbf{2}$ and $\mathbf{3}$ was also studied on P. falciparum lactate dehydrogenase enzyme (PDB ID: 1CET). The total energy and MDS of compound 2, as shown in Table 7, was found to be $108.388 \mathrm{kcal} / \mathrm{mol}$ and $-103.69 \mathrm{kcal} / \mathrm{mol}$. Compound 3 showed values of $79.747 \mathrm{kcal} / \mathrm{mol}$ and $-86.38 \mathrm{kcal} / \mathrm{mol}$ for the total energy and MDS. 
Table 7. The total energy, MDS, and interacting residues of 2 and 3 to $P$. falciparum lactate dehydrogenase enzyme (1CET).

\begin{tabular}{ccccc}
\hline Ligand & $\begin{array}{c}\text { Total Energy } \\
\text { (kcal/mol) }\end{array}$ & $\begin{array}{c}\text { Mol Dock Score } \\
\text { (kcal/mol) }\end{array}$ & Hydrogen Bonding & Steric Interaction \\
\hline $\mathbf{2}$ & 108.388 & -103.69 & Tyr85(2); Phe52 & Tyr85; Glu122(2); Asp53(2); Gly27; \\
$\mathbf{3}$ & 79.747 & -86.38 & $\begin{array}{c}\text { Glu122; Asp53; Tyr85 } \\
\text { Gly29; Gly99; Ser28 }\end{array}$ & $\begin{array}{c}\text { Glu122; Tyr85; Asp53(2); Ile119 } \\
\text { Gly29; Gly99; Ala98; Asp53 }\end{array}$ \\
\hline
\end{tabular}

The interaction analysis indicated that compound 2 bound to 1CET via hydrogen bonding of oxygen atom of hydroxyl chelate group (C1) with Tyr85 residue and oxygen atom of carbonyl with Phe52 residue. The steric interaction was established by xanthone backbone and the dimethylallyl group of compound 2 with Tyr85, Glu122(2), Asp53(2), Gly27, Ala98, and Phe100 residues. The hydrogen bonding was also formed by carbonyl group, chelate hydroxyl, and free hydroxyl (C5) of compound 3 with Tyr85(2) and Phe52 residues. The Glu122, Tyr85, Asp53(2), and Ile119 residues of 1CET bound to carbonyl groups, free hydroxyl (C5), and dimethylallyl group of compound 3 by steric interactions (Figure 3).
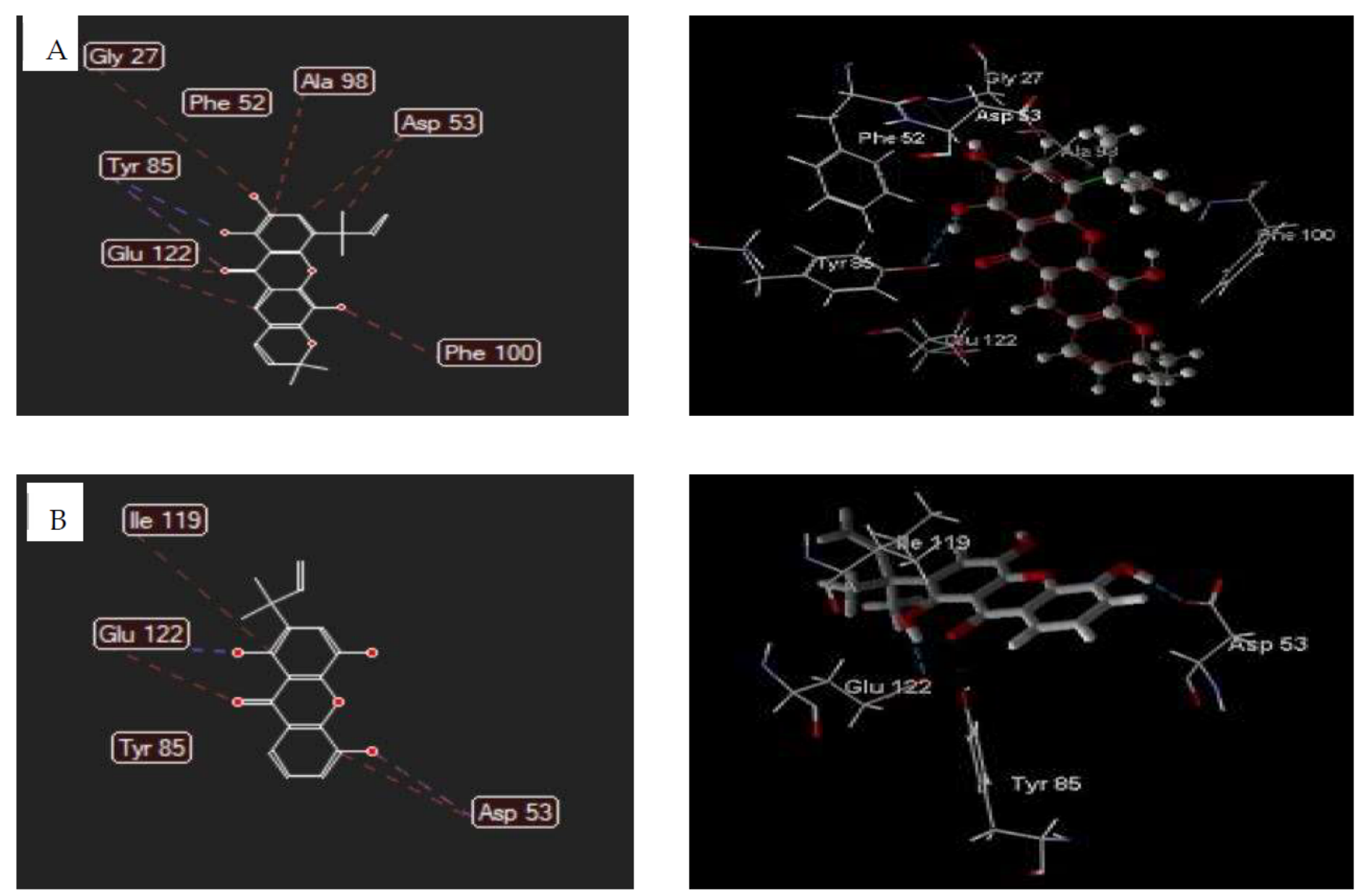

Figure 3. The 2D and 3D interaction of $2(\mathbf{A})$ and 3 (B) with P. falciparum lactate dehydrogenase. Hydrogen bonds were depicted as blue dotted lines while steric interactions were shown as red lines. Carbon atoms were represented in gray, oxygen in red and hydrogen in white.

\subsubsection{ADMET Profiles}

The absorption, distribution, metabolism, excretion, and toxicity properties of isolated compounds 1-5, as derived from ProTox online tool, revealed that all compounds had 
molecular weight less than 500 which is important for penetrability [40]. The Caco-2 permeability for prediction of orally administered drug absorption of compounds $\mathbf{1}, \mathbf{3}$, and 4 was $>0.90$ and, 0.90 for compounds 2 and $\mathbf{5}$ (Table 8). This implied that compounds 1, 3, and 4 had high permeability in contrast to compounds 2 and 5 [41]. Compounds 1-5 showed high intestinal absorption (80-98\%) and would be absorbed in the small intestine [42]. The transdermal efficacy as illustrated by skin permeability of compounds 1-5 was ranging from -2.735 to $-2.851 \mathrm{~cm} /$ hour $(<-2.5)$ which mean that they will penetrate the skin properly. It is known that molecules will show difficulty in the skin penetration if the $\log \mathrm{Kp}$ value were higher than $-2.5 \mathrm{~cm} /$ hour [43]. The circulation in blood plasma (VDss) came out to be acceptable for all compounds 1-5 with value higher than -0.15 [44]. An important parameter for reducing side effects and toxicity represented by penetration via blood-brain barrier (BBB) showed that compounds 2 and 4 will sufficiently be able to penetrate, but compounds 2,3 , and 5 were very low to reach the brain. The CNS permeability signified for the permeability of the blood surface to the central nerve defined that compounds 1-4 with values of -2.89 to -1.679 better than acarbose and chloroquine, were able to permeate a central nervous system [45]. Table 8 informed that isolated xanthones, except 4 were noninhibitors for CYP2D6 and for CYP3A4 and will not interfere the CYP450 biotransformation in general, while compound 4 will be metabolized [46]. In terms of excretion, the total clearance of all compounds shared positive values meaning that they will be discharged quickly except for 5 . The adverse interactions of compounds $\mathbf{1}-\mathbf{5}$ with OCT2 inhibitors as denoted by OCT2 substrate parameter revealed that compounds 1-5 showed no potential contraindication. The toxicity level of compounds 1-5 predicted by using pkCSM-pharmacokinetics for hepatotoxicity and acute oral toxicity in rats $\left(\mathrm{LD}_{50}\right)$ represented the value was in the range 1.889 to 2.057 lower than chloroquine and acarbose with $\mathrm{LD}_{50}$ value 2.888 and 2.495 , respectively. Compound 4 had the highest $\mathrm{LD}_{50}$, of 2.057 and were the most toxic than others [47]. Hepatotoxicity descriptor declared that compounds 4 and 5 cause hepatotoxicity while compounds 1-3 were not hepatotoxic.

Table 8. ADMET properties by ProTox Online Tool.

\begin{tabular}{|c|c|c|c|c|c|c|c|c|c|c|c|c|c|}
\hline \multirow[b]{2}{*}{ Ligands } & \multicolumn{3}{|c|}{ Absorption } & \multicolumn{3}{|c|}{ Distribution } & \multicolumn{2}{|c|}{ Metabolism } & \multicolumn{2}{|c|}{ Excretion } & \multicolumn{3}{|c|}{ Toxicity } \\
\hline & $\begin{array}{l}\text { Caco-2 Per- } \\
\text { meability }\end{array}$ & $\begin{array}{c}\text { Intestinal } \\
\text { Abs }\end{array}$ & $\begin{array}{l}\text { Skin Per- } \\
\text { meability }\end{array}$ & VDss & $\begin{array}{l}\text { BBB Per- } \\
\text { meability }\end{array}$ & $\begin{array}{l}\text { CNS Per- } \\
\text { meability }\end{array}$ & $\begin{array}{l}\text { CYP2D6 } \\
\text { Inhibitors }\end{array}$ & $\begin{array}{c}\text { CYP3A4 } \\
\text { Inhibitors }\end{array}$ & $\begin{array}{c}\text { Total } \\
\text { Clearance }\end{array}$ & $\begin{array}{c}\text { Renal } \\
\text { OCT2 } \\
\text { Substrate }\end{array}$ & $\begin{array}{l}\text { Oral Rat } \\
\text { Acute } \\
\text { Toxicity } \\
\text { (LD50) }\end{array}$ & $\begin{array}{c}\text { Oral Rat } \\
\text { Chronic } \\
\text { Toxicity } \\
\text { (LOAEL) }\end{array}$ & $\begin{array}{l}\text { Hepato } \\
\text { Toxicity }\end{array}$ \\
\hline 1 & 1.233 & 95.93 & -2.851 & 0.039 & -0.291 & -2.098 & No & No & 0.655 & No & 2.045 & 1.449 & No \\
\hline 2 & 0.736 & 98.018 & -2.735 & 0.046 & -1.258 & -1.93 & No & No & 0.186 & No & 1.889 & 0.696 & No \\
\hline 3 & 1.298 & 96.82 & -2.735 & 0.068 & -1.02 & -2.029 & No & No & 0.198 & No & 2.055 & 0.633 & No \\
\hline 4 & 0.989 & 94.818 & -2.754 & 0.143 & 0.099 & -1.679 & No & Yes & 0.176 & No & 2.057 & 0.313 & Yes \\
\hline 5 & 0.335 & 80.007 & -2.735 & -0.014 & -1.36 & -3.040 & No & No & -0.102 & No & 2.036 & 1.695 & Yes \\
\hline Chloroquine & 1.259 & 89.440 & -2.564 & 1.757 & 0.410 & -2.687 & Yes & No & 0.993 & Yes & 2.888 & 0.423 & Yes \\
\hline Acarbose & -0.278 & 0 & -2.735 & -0.644 & -1.854 & -7.308 & No & No & 0.546 & No & 2.495 & 7.203 & No \\
\hline
\end{tabular}

\section{Conclusions}

In this study, five known xanthones 1-5 was first reported from G. forbesii. The compounds were isolated from the $\mathrm{CH}_{2} \mathrm{Cl}_{2}$ extract, and their structure were determined by spectroscopic analysis and literature data comparison. The antioxidant evaluation indicated compounds 3 had the highest reducing activity $\left(203.9 \pm 1.19 \mu \mathrm{M} \mathrm{Fe}^{2+} / \mathrm{g}\right)$ and ABTS assay $\left(\mathrm{IC}_{50} 0.05 \pm 0.01 \mu \mathrm{M}\right)$ among others. Compound 5 had the highest $\alpha$-glucosidase inhibition activity with $\mathrm{IC}_{50}$ values of $37.4 \pm 1.20 \mu \mathrm{M}$ using sucrose and $91.0 \pm 1.14 \mu \mathrm{M}$ using maltose as substrates. The $\mathrm{IC}_{50}$ value of compound 4 against $\alpha$-amylase was $10.8 \pm 0.04 \mu \mathrm{M}$. The antiplasmodial assay revealed that compounds $\mathbf{2}$ and $\mathbf{3}$ were active against $P$. falciparum strain 3D7 with $\mathrm{IC}_{50} 3.3 \pm 0.04 \mu \mathrm{M}$ and $5.0 \pm 0.04 \mu \mathrm{M}$. The in silico molecular docking of selected xanthones was studied against human lysosomal acid-alpha-glucosidase (5NN8) and $P$. falciparum lactate dehydrogenase enzymes (1CET). Results from ADMET prediction analyzed using ProTox online tool showed most of compounds generally display good absorption, distribution, metabolism, excretion, and toxicity properties. 
Author Contributions: Conceptualization, T.E.; data curation, E.R.S. and A.F.; formal analysis, J.W., E.R.S., A.F. and A.S.P.; methodology, T.E., J.W. and E.R.S.; resources, T.E. and M.T.; supervision, T.E., A.F. and A.S.P.; writing—original draft, J.W. and M.T.; writing—review and editing, E.R.S., A.F., A.S.P. and M.T. All authors have read and agreed to the published version of the manuscript.

Funding: This study financially supported by the Ministry of Research, Technology and Higher Education, Indonesia (Contract Number 3/E1/KP.PTNBH/2021).

Institutional Review Board Statement: Not applicable.

Informed Consent Statement: Not applicable.

Data Availability Statement: The data presented in this study are available on request from the corresponding author.

Acknowledgments: The authors would like to thank Siswandono for helping the molecular docking data and the Rector of the University Halmahera, Herson Keradjaan, for the permission to study doctoral program.

Conflicts of Interest: The authors declare no conflict of interest.

$\begin{array}{ll}\text { Abbreviations } \\ \text { DPPH } & \text { 2,2-Diphenyl-2-picrylhydrazyl } \\ \text { ABTS } & \text { 2,2-azinobis-3-ethylbenzothia-zoline-6-sulfonic acid } \\ \text { FRAP } & \text { ferric reducing-antioxidant power } \\ \text { ADMET } & \text { absorption distribution metabolism excretion toxicity } \\ \text { TPTZ } & \text { 2,4,6 tris(2-pyridyl)-s-triazine } \\ \text { MDS } & \text { mol dock score } \\ \text { pkCSM } & \text { small-molecule pharmacokinetics prediction } \\ \text { PDB } & \text { protein data bank }\end{array}$

\section{References}

1. Perry, L.M.; Metzger, J. Attributed properties and uses. In Medicinal Plants of East and Southeast Asia; MIT Press: Cambridge, MA, USA, 1980; 620p.

2. Aravind, A.P.A.; Menon, L.N.; Rameshkumar, K.B. Structural diversity of secondary metabolites in Garcinia species. In Diversity of Garcinia Spesies in the Western Ghats: Phytochemical Perspective; Ramesshkumar, K.B., Ed.; JNTBGRI: Kerala, India, 2016; pp. 19-75.

3. Subhashini, N.; Nagarajan, G.; Kavimani, S. In vitro antioxidant and anticholinesterase activities of G. combogia. Int. J. Pharm. Pharm. Sci. 2011, 3, 129-132.

4. Meng, F.; Hui-Jin, F.; Yu, C.; De-Bin, W.; Guang-Zhong, Y. Antioxidant activity of Garcinia xanthochymus leaf, root and fruit extracts in vitro. Chin. J. Nat. Med. 2012, 10, 129-134.

5. Hay, A.-E.; Hélesbeux, J.-J.; Duval, O.; Labaïed, M.; Grellier, P.; Richomme, P. Antimalarial xanthones from Calophyllum caledonicum and Garcinia vieillardii. Life Sci. 2004, 75, 3077-3085. [CrossRef]

6. Monzote, L.; Cuesta-Rubio, O.; Matheeussen, A.; Van Assche, T.; Maes, L.; Cos, P. Antimicrobial Evaluation of the Polyisoprenylated Benzophenones Nemorosone and Guttiferone A: Antimicrobial evaluation of polyisoprenylated benzophenones. Phytother. Res. 2011, 25, 458-462. [CrossRef]

7. Auranwiwat, C.; Laphookhieo, S.; Rattanajak, R.; Kamchonwongpaisan, S.; Pyne, S.G.; Ritthiwigrom, T. Antimalarial polyoxygenated and prenylated xanthones from the leaves and branches of Garcinia mckeaniana. Tetrahedron 2016, 72, 6837-6842. [CrossRef]

8. Trinh, B.T.D.; Quach, T.T.T.; Bui, D.N.; Staerk, D.; Nguyen, L.-H.D.; Jäger, A.K. Xanthones from the twigs of Garcinia oblongifolia and their antidiabetic activity. Fitoterapia 2017, 118, 126-131. [CrossRef] [PubMed]

9. Nguyen, C.N.; Trinh, B.T.D.; Tran, T.B.; Nguyen, L.-T.T.; Jäger, A.K.; Nguyen, L.-H.D. Anti-diabetic xanthones from the bark of Garcinia xanthochymus. Bioorg. Med. Chem. Lett. 2017, 27, 3301-3304. [CrossRef] [PubMed]

10. Noor, O.D.A.; Senin, T.D. Mundar (Garcinia forbesii) Si Manggis Merah Sumber Daya Genetik Kalimantan Selatan. 2017. Available online: http:/ / kalsel.litbang.pertanian.go.id/ (accessed on 13 September 2021).

11. Harrison, L.J.; Leong, L.-S.; Sia, G.-L.; Sim, K.-Y.; Tan, H.T.-W. Xanthones from Garcinia forbesii. Phytochemistry 1993, 33, 727-728. [CrossRef]

12. Arteaga-Crespo, Y.; Radice, M.; Bravo-Sanchez, L.R.; García-Quintana, Y.; Scalvenzi, L. Optimisation of ultrasound-assisted extraction of phenolic antioxidants from Ilex guayusa Loes. leaves using response surface methodology. Heliyon 2020, 6, e03043. [CrossRef] [PubMed] 
13. Szydłowska-Czerniak, A.; Łaszewska, A. Effect of refining process on antioxidant capacity, total phenolics and prooxidants contents in rapeseed oils. LWT Food Sci. Technol. 2015, 64, 853-859. [CrossRef]

14. Worawalai, W.; Rattanangkool, E.; Vanitcha, A.; Phuwapraisirisan, P.; Wacharasindhu, S. Concise synthesis of (+)-conduritol F and inositol analogues from naturally available (+)-proto-quercitol and their glucosidase inhibitory activity. Bioorg. Med. Chem. Lett. 2012, 22, 1538-1540. [CrossRef]

15. Unuofin, J.O.; Otunola, G.A.; Afolayan, A.J. In vitro $\alpha$-amylase, $\alpha$-glucosidase, lipase inhibitory and cytotoxic activities of tuber extracts of Kedrostis africana (L.) Cogn. Heliyon 2018, 4, e00810. [CrossRef]

16. Wang, X.; Miyazaki, Y.; Inaoka, D.K.; Hartuti, E.D.; Watanabe, Y.-I.; Shiba, T.; Harada, S.; Saimoto, H.; Burrows, J.N.; Benito, F.J.G.; et al. Identification of Plasmodium falciparum Mitochondrial Malate: Quinone Oxidoreductase Inhibitors from the Pathogen Box. Genes 2019, 10, 471. [CrossRef]

17. Rossignol, F.; Solares, M.; Balanza, E.; Coudert, J.; Clottes, E. Expression of lactate dehydrogenase A and B genes in different tissues of rats adapted to chronic hypobaric hypoxia. J. Cell. Biochem. 2003, 89, 67-79. [CrossRef]

18. Díaz, A.B.; Vera, J.R.; Cote, V.; Bruno-Colmenárez, J.; de Delgado, G.D. NMR elucidation and crystal structure analysis of 1-hydroxy-3,6- dimethoxy-8-methyl-9h-xanthen-9-one (lichexanthone) isolated from Vismia baccifera (Guttiferae). Bol. Latinoam. Caribe Plantas Med. Aromát. 2010, 9, 470-474.

19. Masters, K.-S.; Bras, S. Xanthones from Fungi, Lichens, and Bacteria: The Natural Products and Their Synthesis. Chem. Rev. 2012, 112, 3717-3776. [CrossRef] [PubMed]

20. Iinuma, M.; Tosa, H.; Tanaka, T.; Asai, F.; Shimano, R. Two xanthones with a 1,1-dimethylallyl group in root bark of Garcinia subelliptica. Phytochemistry 1995, 39, 945-947. [CrossRef]

21. Zhong, F.; Chen, Y.; Wang, P.; Feng, H.; Yang, G. Xanthones from the Bark of Garcinia xanthochymus and their 1,1-Diphenyl-2picrylhydrazyl Radical-Scavenging Activity. Chin. J. Chem. 2009, 27, 74-80. [CrossRef]

22. Thepthong, P.; Phongpaichit, S.; Carroll, A.R.; Voravuthikunchai, S.P.; Mahabusarakam, W. Prenylated xanthones from the stem bark of Garcinia dulcis. Phytochem. Lett. 2017, 21, 32-37. [CrossRef]

23. Kamiyama, A.; Mima, Y.; Kodama, M. Prenylated Xanthones From Garcinia Subelliptica. Phytochemistry 1991, 30, $3433-3436$.

24. Sordat-Diserens, I.; Marston, A.; Hamburger, M.; Hostettmann, K.; Rogers, C. Novel Prenylated Xanthones from Garcinia gerrardii HARVEY. Helv. Chim. Acta 1989, 72, 1001-1007. [CrossRef]

25. Bendary, E.; Francis, R.R.; Ali, H.M.G.; Sarwat, M.I.; El Hady, S. Antioxidant and structure-activity relationships (SARs) of some phenolic and anilines compounds. Ann. Agric. Sci. 2013, 58, 173-181. [CrossRef]

26. Lulan, T.Y.K.; Fatmawati, S.; Santoso, M.; Ersam, T. $\alpha$-VINIFERIN as a potential antidiabetic and antiplasmodial extracted from Dipterocarpus littoralis. Heliyon 2020, 6, e04102. [CrossRef]

27. Kainama, H.; Fatmawati, S.; Santoso, M.; Papilaya, P.M.; Ersam, T. The Relationship of Free Radical Scavenging and Total Phenolic and Flavonoid Contents of Garcinia lasoar PAM. Pharm. Chem. J. 2020, 53, 1151-1157. [CrossRef]

28. Shahidi, F.; Zhong, Y. Measurement of antioxidant activity. J. Funct. Foods 2015, 18, 757-781. [CrossRef]

29. Munteanu, I.G.; Apetrei, C. Analytical Methods Used in Determining Antioxidant Activity: A Review. Int. J. Mol. Sci. 2021, 22, 3380. [CrossRef] [PubMed]

30. Tran, T.H.; Nguyen, V.T.; Le, H.T.; Nguyen, H.M.; Tran, T.H.; Do Thi, T.; Nguyen, X.C.; Ha, M.T. Garcinoxanthones S-V, new xanthone derivatives from the pericarps of Garcinia mangostana together with their cytotoxic and antioxidant activities. Fitoterapia 2021, 151, 104880. [CrossRef] [PubMed]

31. De Mello, R.F.A.; de Souza Pinheiro, W.B.; Benjamim, J.K.F.; de Siqueira, F.C.; Chisté, R.C.; Santos, A.S. A fast and efficient preparative method for separation and purification of main bioactive xanthones from the waste of Garcinia mangostana L. by high-speed countercurrent chromatography. Arab. J. Chem. 2021, 14, 103252. [CrossRef]

32. Francik, R.; Szkaradek, N.; Zelaszczyk, D.; Marona, H. Antioxidant activity of xanthone derivatives. Acta Pol. Pharm. Drug Res. 2016, 73, 1505-1509.

33. Abbas, G.; Al-Harrasi, A.S.; Hussain, H. $\alpha$-Glucosidase Enzyme Inhibitors from Natural Products. In Discovery and Development of Antidiabetic Agents from Natural Products; Elsevier: Amsterdam, The Netherlands, 2017; pp. 251-269. [CrossRef]

34. Nichols, B.L.; Baker, S.S.; Quezada-Calvillo, R. Metabolic Impacts of Maltase Deficiencies. J. Pediatr. Gastroenterol. Nutr. 2018, 66, S24-S29. [CrossRef]

35. Tysoe, C.; Williams, L.K.; Keyzers, R.; Nguyen, N.T.; Tarling, C.; Wicki, J.; Goddard-Borger, E.D.; Aguda, A.H.; Perry, S.; Foster, L.J.; et al. Potent Human $\alpha$-Amylase Inhibition by the $\beta$-Defensin-like Protein Helianthamide. ACS Cent. Sci. 2016, 2, $154-161$. [CrossRef]

36. Williams, J.A. Amylase. Pancreapedia Exocrine Pancreas Knowledge Base; APA: Los Angeles, CA, USA, 2017. [CrossRef]

37. Tahghighi, A.; Mehrizi, A.; Zakeri, S. In vitro anti-plasmodial activity of new synthetic derivatives of 1-(heteroaryl)-2- ((5nitroheteroaryl) methylene) hydrazine. Asian Pac. J. Trop. Med. 2021, 14, 128-138.

38. Malebo, H.M.; D'Alessandro, S.; Ebstie, Y.A.; Sorè, H.; Tenoh Guedoung, A.R.; Katani, S.J.; Parapini, S.; Taramelli, D.; Habluetzel, A. In vitro Multistage Malaria Transmission Blocking Activity of Selected Malaria Box Compounds. Drug Des. Dev. Ther. 2020, 14, 1593-1607. [CrossRef]

39. Feroz Khan, F.; Alam, S. QSAR and docking studies on xanthone derivatives for anticancer activity targeting DNA topoisomerase II $\alpha$. Drug Des. Dev. Ther. 2014, 8, 183-195. [CrossRef] [PubMed] 
40. Ekowati, J.; Diyah, N.W.; Nofianti, K.A.; Hamid, I.S. Molecular Docking of Ferulic Acid Derivatives on P2Y12 Receptor and their ADMET Prediction. J. Math. Fundam. Sci. 2018, 50, 203-219. [CrossRef]

41. Angelis, I.D.; Turco, L. Caco-2 Cells as a Model for Intestinal Absorption. Curr. Protoc. Toxicol. 2011, 47, 20-26. [CrossRef]

42. Fagerholm, U. Prediction of human pharmacokinetics gastrointestinal absorption. J. Pharm. Pharmacol. 2006, 59, 905-916. [CrossRef] [PubMed]

43. Cheng, F.; Li, W.; Zhou, Y.; Shen, J.; Wu, Z.; Liu, G.; Lee, P.W.; Tang, Y. admetSAR: A Comprehensive Source and Free Tool for Assessment of Chemical ADMET Properties. J. Chem. Inf. Model. 2012, 52, 3099-3105. [CrossRef]

44. Pires, D.E.V.; Blundell, T.L.; Ascher, D.B. pkCSM: Predicting Small-Molecule Pharmacokinetic and Toxicity Properties Using Graph-Based Signatures. J. Med. Chem. 2015, 58, 4066-4072. [CrossRef]

45. Nau, R.; Sorgel, F.; Eiffert, H. Penetration of Drugs through the Blood-Cerebrospinal Fluid/Blood-Brain Barrier for Treatment of Central Nervous System Infections. Clin. Microbiol. Rev. 2010, 23, 858-883. [CrossRef]

46. Backman, J.T.; Filppula, A.M.; Niemi, M.; Neuvonen, P.J. Role of Cytochrome P450 2C8 in Drug Metabolism and Interactions. Pharmacol. Rev. 2016, 68, 168-241. [CrossRef] [PubMed]

47. Domínguez-Villa, F.X.; Durán-Iturbide, N.A.; Ávila-Zárraga, J.G. Synthesis, molecular docking, and in silico ADME/Tox profiling studies of new 1-aryl-5-(3-azidopropyl) indol-4-ones: Potential inhibitors of SARS CoV-2 main protease. Bioorg. Chem. 2021, 106, 104497. [CrossRef] [PubMed] 